\title{
STRATEGI PEMASARAN USAHA MIKRO, KECIL DAN MENENGAH (UMKM) BATIK MAGENDA TAMANAN KABUPATEN BONDOWOSO
}

\author{
Dewi Jayanti Mandasari ${ }^{1}$, Joko Widodo ${ }^{1}$,Sutrisno Djaja ${ }^{1}$ \\ ${ }^{1}$ Program studi Pendidikan Ekonomi, Fakultas Keguruan dan Ilmu Pendidikan, Universitas Jember \\ E-mail:dewi.debby13@yahoo.com
}

\begin{abstract}
Abstrak
Usaha Mikro Kecil Dan Menengah merupakan suatu usaha yang berperan penting dalam perekonomian nasional. Pada saat ini UMKM gencar dijalankan di berbagai daerah di Indonesia. Salah satu daerah yang menjalankan usaha tersebut adalah Bondowoso, di sana banyak terdapat UMKM yang didirikan, salah satunya pada bidang usaha kerajinan Batik Magenda Tamanan Kabupaten Bondowoso. Adapun rumusan masalah penelitian ini adalah Bagaimana strategi pemasaran yang dilakukan oleh UMKM Batik Magenda Tamanan Kabupaten Bondowoso dalam mengembangkan usahanya? dalam penelitian ini memiliki tujuan untuk mengetahui strategi pemasaran UMKM Batik Magenda Tamanan Kabupaten Bondowoso dalam mengembangkan usahanya. Diharapkan penelitian ini memiliki manfaat secara toeritis dan praktis yang akan membantu dalam menerapakan strategi pemasaran dalam mengembangkan usaha. Pada penelitian ini menggunakan jenis penelitian kualitatif deskripsif, yang mana teknik penentuan tempat menggunakan metode purposive area, dalam hal ini penelitian yang menggunakan purposive sampling dalam Usaha mikro kecil dan menengah (UMKM) merupakan suatu usaha yang berperan penting dalam perekonomian nasional. Pada saat ini UMKM gencar dijalankan di berbagai daerah di Indonesia. Salah satu daerah yang menjalankan usaha tersebut adalah Bondowoso, di sana banyak terdapat UMKM yang didirikan dan melakukan penggalian data. Setelah data peroleh peneliti menganalisis data dengan melakukan Data Reduction, Data Display, Penarikan Kesimpulan. Hasil penelitian menunjukkan bahwa dengan menerapkan strategi pemasaran $4 \mathrm{p}$ dapat memberikan perkembangan dalam usaha yang di jalankan oleh UMKM Batik Magenda Tamanan Kabupaten Bondowoso.
\end{abstract}

Kata Kunci: Strategi Pemasaran, UMKM

\section{PENDAHULUAN}

Usaha mikro kecil dan menengah (UMKM) merupakan suatu usaha yang berperan penting dalam perekonomian nasional. Pada saat ini UMKM gencar dijalankan di berbagai daerah di Indonesia. Salah satu daerah yang menjalankan usaha tersebut adalah Bondowoso, di sana banyak terdapat UMKM yang didirikan dan menjalankan usaha-usaha tertentu salah satunya pada bidang usaha kerajinan batik. Peranan UMKM yang fleksibelitas mampu menyerap tenaga kerja dengan cepat tanpa memandang tinggi rendahnya pendidikan para tenaga kerjanya. Sehingga UMKM ini selain berperan penting dalam ekonomi nasional juga berperan menanggulangi tingkat pengangguran.UMKM sebenarnya memiliki jaringan pasar yang cukup luas di dunia Internasional.

Adapun permasalahan yang dihadapi oleh UMKM khususnya industri kerajinan batik, yaitu persaingan pasar dalam memasarkan produknya, karena pada saat ini banyak usaha yang menjalankan usahanya pada bidang batik. Salah satu UMKM yang menjalankan usaha tersebut, yaitu Batik Magenda Tamanan Bondowoso. Batik Magenda merupakan industri kecil atau dapat di kategorikan sebagai Usaha Mikro Kecil Dan Menengah (UMKM) batik yang ada didaerah Tamanan kabupaten Bondowoso yang di rintis oleh 7 orang yang mempunyai kreatifitas yang sangat tinggi, awalnya Batik Magenda merupakan gabungan usaha yang didirikan oleh pihak Lembaga Sekolah Menengah Kejuruan (SMK Tamanan) namun sejak tahun 2015 sanggar batik yang dirikan oleh SMK terpisah menjadi 2, yaitu sanggar batik baska dan sanggar Batik Magenda. Batik Magenda ini sudah terlepas dari tanggungjawab pihak SMK, dan sekarang Batik Magenda sudah menjalankan usahanya sendiri. Batik Magenda banyak mengalami perkembangan sejak menjalankan usahanya sendiri dari pada saat dibawah naungan Lembaga Sekolah Menengah Kejuruan, yang setiap bulan omset penjualannya selalu mengalami peningkatan. Selain itu, Batik Magenda sering mengikuti kegiatan pameran baik yang diadakan secara rutin dan event -event tertentu.

UMKM Batik Magenda dalam menjalankan usahanya perlu adanya usaha yang sangat keras karena banyaknya persaingan yang lebih dahulu serta lebih berpengalaman dalam menjalankan usaha batik. Oleh sebab itu, mereka harus mampu mengembangkan usaha yang mereka jalankan dengan baik terkait dalam pembuatan produk dan strategi pemasarannya. Sebagai pemula dalam hal tersebut perlu adanya pengetahuan yang sangat luas dalam mencari jaringan pemasaran Batik Magenda. Dalam UMKM Batik Magenda yang rata- rata pemilik 
dan karyawannya masih berusia dibawah umur 25 tahun dan memiliki riwayat pendidikan yang relatif rendah sehingga mereka hanya mempunyai sedikit pengetahuan akan pemasaran. Akan tetapi, mereka dapat mengembangkan usahanya meskipun masih dalam pasar lokal.

Strategi pemasaran adalah salah satu cara memenangkan keunggulan bersaingan yang berkesinambungan untuk perusahaan yang memproduksi barang atau jasa. Strategi pemasaran dapat dipandang sebagai salah satu dasar yang dipakai dalam menyusun perencanaan usaha secara menyeluruh. Semakin kerasnya persaingan yang dihadapi oleh UMKM pada umumnya, dengan situasi tersebut UMKM harus memiliki strategi pemasaran untuk menghadapi persaingan antar UMKM. Pemasaran perlu mendapat perhatian serius oleh UMKM terutama dalam proses penetapan streategi pemasaran yang dipilih akan mampu menembus pasar. Apalagi kondisi persaingan yang semakin ketat seperti saat ini, kemampuan untuk merebut pangsa pasar akan dihadapi UMKM itu sendiri. Keadaan ini tidak terkecuali akan dihadapi oleh Batik Magenda Tamanan Bondowoso.

Berdasarkan latar belakang di atas, maka peneliti melakukan penelitian dengan judul "Strategi Pemasaran Usaha Mikro Kecil Dan Menengah (Umkm) Batik Magenda Tamanan Kabupaten Bondowoso”.

\section{METODE PENELITIAN}

Penelitian ini merupakan jenis penelitian deskriptif kualitatif yang diuraikan dengan kata-kata menurut pendapat subjek penelitian. Metode penentuan lokasi penelitian menggunakan metode purposive area, yaitu pemilihan tempat penelitian yang disesuaikan dengan tujuan penelitian. Adapun lokasi penelitian yang ditetapkan oleh peneliti yaitu UMKM Batik Magenda Tamanan kabupaten Bondowoso. Metode penentuan informan penelitian menggunakan metode purposive sampling. Adapun informan utama dalam penelitian ini adalah manajer Umkm batik magenda. Jenis dan sumber data berupa data primer dan data sekunder. Adapun data primer dalam penelitian ini yaitu data yang diperoleh secara langsung dari subjek atau manajer umkm batik magenda yang melalui wawancara dengan subjek/ narasumber yang berkaitan dengan strategi pemasaran yang digunakan dan data sekunder berupa dokumen-dokumen, seperti data jumlah karyawan, kegiatan strategi pemasaran yang dilakukan UMKM Batik Magenda Tamanan Kabupaten Bondowoso, dan profil umkm batik magenda.

Metode pengumpulan data menggunakan metode wawancara dan dokumentasi. Dalam metode wawancara dalam penelitian ini dilakukan terhadap manajer UMKM Batik Magenda, selain itu wawancara dilakukan tehadap informan tambahan yang merupakan karyawan umkm batik magenda. Adapun metode dokumentasi berupa datadata tertulis atau dokumen yang berkaitan dengan data jumlah karyawan, kegiatan strategi pemasaran yang dilakukan UMKM Batik Magenda Tamanan Kabupaten Bondowoso, dan profil umkm batik magenda. Analisis data dilakukan dengan cara reduksi data, display data, dan penarikan kesimpulan.

\section{HASIL DAN PEMBAHASAN}

\section{Hasil Penelitian}

Berdasarkan penelitian yang telah dilakukan, maka dapat diketahui bahwa strategi pemasaran yang diterapkan oleh UMKM Batik Magenda Tamanan Kabupaten Bondowoso, antara lain strategi produk, strategi harga, strategi tempat dan strategi promosi. Produk yang dikembangkan UMKM Batik Magenda Tamanan Kabupaten Bondowoso awalnya tidak bervariasi, produk yang ditawarkan hanyalah sebatas Batik Cap dan Batik Tulis yang motifnya masih belum bervariatif. Hal ini sesuai dengan apa yang dikemukakan oleh manajer UMKM Batik Magenda Tamanan Kabupaten Bondowoso yang menyatakan pada

“ Awalnya batik magenda hanya menjual dua produk saja. Namun seiring jalannya waktu usaha kami semakin berkembang pesat sehingga muncul variasi dan inovasi produk yang baru”. Sanggar batik magenda berawal dari outlet kecil dijalan sukowono kecamatan Tamanan kabupaten Bondowoso yang dirintis mulai dari nol kini semakin berkembang".

Berdasarkan pernyataan manajer Batik Magenda Tamanan Kabupaten Bondowoso dapat diketahui bahwa, pada awalnya memang bisnis ini dirintis dari nol. Produk yang ditawarkan hanyalah dua produk saja yaitu Batik Cap dan Batik Tulis. Namun dengan berjalannya waktu sanggar Batik Magenda menciptakan inovasi baru dan menciptakan produk baru yaitu Batik Semi dan Batik Abstrak. UMKM Batik Magenda juga selalu mengutamakan kualitas produk yang di produksinya, mulai dari bahan baku seperti kain dan pewarna yg memiliki nilai atau kualitas yang berbeda. Harga merupakan jumlah uang yang dibutuhkan untuk mendapatkan sejumlah produk dan pelayanan yang maksimal. Pencapaian harga secara tepat dan kompetitif akan mempengaruhi keberhasilan suatu usaha dalam melakukan kegiatan pemasaran. Hal ini sesuai dengan yang dikemukakan oleh manajer UMKM Batik Magenda Tamanan Kabupaten Bondowoso yang menyatakan:

"Menentukan harga produk batik dengan harga terjangkau. Penetapan harga disesuaikan dengan tingkat kesulitan membatik, kualitas produk batik serta daya beli konsumen. Dalam menetapkan harga juga membandingkan dengan harga jual produk pesaing batik sejenis". $\left(Z .27^{\text {th }}\right)$. 
Berdasarkan pernyataan tersebut dapat diketahui bahwa dalam menentukan harga suatu produk UMKM Batik Magenda Tamanan Kabupaten Bondowoso juga melihat dari segi harga bahan baku, tingkat kerumitan dalam membatik, kualitas produk, daya beli konsumen dan harga jual produk pesaing yang sejenis. Pernyataan dari manajer juga didukung dengan pernyataan karyawan bagian maketing yang menyatakan.

"Dalam menentukan harga jual produk kami membuat patokan dari harga bahan baku batik dan harga jual produk pesaing yang sejenis dengan produk kami, hal ini dilakukan agar produk kami tidak kalah bersaing dengan produk pesaing yang sejenis dan sesuai dengan kemampuan daya beli konsumen”. (H. $22^{\text {th }}$.

Pernyataan tersebut diperkuat dengan pernyataan sekertaris UMKM Batik Magenda Tamanan Kabupaten Bondowoso yang menyatakan:

"kami dalam menentukan harga jual produk itu sebenarnya banyak mengalami kesulitan karena apabila harga kain ataupun bahan baku pewarna itu mengalami kenaikan kami tidak bisa semertamerta menaikkan harga ataupun mengurangi kualitas produk”. (S.29 $\left.{ }^{\text {th }}\right)$

Berdasarkan pernyataan diatas menjelaskan bahwa strategi harga merupakan suatu hal yang harus benarbenar dipertimangkan secara detail karena dengan harga-harga tertentu dapat menarik banyak minat konsumen diberbagai kalangan masyarakat dan dengan kualitas yang sesuai. Sehingga dapat meningkatkan minat konsumen untuk membeli produk yang dihasilkan oleh UMKM Batik Magenda Tamanan Kabupaten Bondowoso.

Tempat atau saluran distribusi pemasaran dengan nama yang mudah diingat, mudah ditemukan dan terletak di lokasi yang strategis akan sangat membantu dalam kegiatan pemasaran suatu usaha dan memudahkan konsumen dalam menjangkau lokasi usaha tersebut. Hal ini sesuai dengan yang dikemukakan oleh manajer Batik Magenda Tamanan Kabupaten Bondowoso yang menyatakan:

"Dalam menentukan lokasi pemasaran UMKM Batik Magenda Tamanan Kabupaten Bondowoso memilih tempat didaerah perbatasan diantara kabupaten Bondowoso dan Kabupaten Jember karena lokasi yang seperti ini kami dapat memperoleh konsumen dari kedua kabupaten sekaligus dan memudahkan para konsumen untuk menangkau lokasi Batik Magenda”.(Z.27 th).

Pernyataaan diatas menjelaskan bahwa pemilik UMKM Batik Magenda dalam memilih lokasi atau tempat didaerah perbatasan kabupaten, menurut pendapat beliau dengan memilih tempat diperbatasan ini dapat memberikan kontribusi yang sangat efektif untuk meningkatkan volume penjualan batik dan juga dapat menarik minat pelanggan yang tidak hanya dari daerahnya saja tetapi juga dari luar daerahnya.

Tempat merupakan aspek yang sangat penting dalam suatu usaha. Batik Magenda memilih tempat di Kecamatan Tamanan karena tempatnya strategis yang berada didaerah perbatasan antara kabupaten Bondowoso dan Kabupaten Jember ini sangat memungkin bagi pihak UMKM Batik Magenda untuk mendapatkan konsumen yang berasal dari Jember tidak hanya konsumen dari Bondowoso saja. Hal ini juga didukung dengan pernyataan karyawan bagian pemasaran yang menyatakan:

"lokasi usaha kami berada dikawasan yang strategis dan tepat sasaran dalam artian sasaran yang kami maksud adalah masyarakat diberbagai kalangan yang ada didaerah Bondowoso sendiri maupun yang dari daerah Jember.( H.22 $\left.2^{\text {th }}\right)$."

Sesuai data yang diperoleh diketahui bahwa UMKM Batik Magenda Tamanan Kabupaten Bondowoso selalu berusaha untuk meningkatkan penjualan produknya di pasar dengan melalui penguatan aspek promosi, iklan yang semakin efektif dan varitif sesuai target pasar. Iklan dan promosi merupakan aspek yang paling penting dalam suatu usaha, karena melalui iklan dan promosi sebuah produk pada perusahaan tertentu akan lebih dikenal oleh konsumen. Hal ini sesuai dengan yang dikemukakan oleh manajer Batik Magenda yang menyatakan:

"Promosi kami mulalui media internet yaitu situs jejaring sosial facebook sanggar batik magenda dan melalui event - event tertentu yang sering kita ikuti dengan tujuan untuk mempromosikan produk kami kepada konsumen, dengan memasarkan produk melalui pemasaran yang manual maupun memasarkan secara online bisa menjangkau konsumen secara luas tidak hanya konsumen didalam kabupaten Bondowoso". (Z.27th)

Berdasarkan pernyataan diatas dapat diketahui bahwa Batik Magenda dalam memasarkan produknya melalui situs jejaring sosial facebook: sanggar Batik Magenda, website: batikmagenda.com, manual dan event event tertentu. Pernyataan tersebut didukung oleh pernyataan karyawan bagian pemasaran/ marketing yang menyatakan:

“Awalnya Batik Magenda Tamanan Kabupaten Bondowoso dibuka tepatnya pada tanggal 10 Oktober 2015. Kami datang ke instansi - instansi, kelembaga - lembaga sekolah dan kediskomperindak, inilah cara promosi awal yang kami lakukan mbak agar batik magenda lebih dikenal masyarakat. Kami juga mengikuti event - event tertentu yang diadakan di jember misalnya festival muharrom, pameran batik dan masih banyak lagi lainnya. Semua itu dilakukan untuk mempromosikan produk kami kepada konsumen". (H.22 $\left.2^{\text {th }}\right)$

Berdasarkan pertanyaan diatas dapat diketahui bahwa promosi yang dilakukan oleh UMKM Batik Magenda 
Tamanan Kabupaten Bondowoso cukup sederhana dengan cara promosi yang dilakukan. Selain dengan cara diatas dalam mempromosikan produknya Batik Magenda Tamanan saat ini menggunakan media sosial dalam mempromosikan produknya seperti facebook sanggar Batik Magenda, promosi melalui dunia maya selain murah juga sangat efektif membantu dalam memperkenalkan kepada masyarakat, selain itu pihak UMKM Batik Magenda juga mempromosikan melalui event-event tertentu yang diadakan di Bondowoso maupun diluar Bondowoso seperti festival muharrom, pameran batik dll. Promosi melalui pembicaraan dari konsumen yang sudah membeli kepada calon konsumen lainnya juga dirasa sangat membantu dalam meningkatkan volume penjualan kami.

\section{Pembahasan}

Berdasarkan hasil penelitian yang telah dilakukan di UMKM Batik Magenda Tamanan Kabupaten Bondowoso peneliti menentukan strategi yang digunakan adalah marketing mix atau strategi bauran pemasaran. Manajer UMKM Batik Magenda mengatakan bahwa dalam strategi pemasaran, UMKM Batik Magenda berusaha memaksimalkan produk yang berkualitas, harga yang mempunyai daya saing, dan memasarkan produk sebaik mungkin. Keadaan tersebut menujukkan bahwa produk, harga, dan cara memasarkan produk merupakan bagian dari unsur bauran pemasaran. Hal ini dilakukan oleh pemilik UMKM Batik Magenda dengan tujuan untuk menarik minat konsumen agar membeli produk yang dihasilkan.

UMKM Batik Magenda dalam memproduksi barang dan jasa dengan tetap menjaga kualitas produk dan inovasi motif batik. Dengan menjaga kualitas produk yang dihasilkan akan memberikan dampak terhadap kepuasan dan kepercayaan konsumen kepada UMKM Batik Magenda sendiri. Peningkatan produk yang dilakukan oleh UMKM Batik Magenda dengan cara menambah variasi dan motif batik, serta pemilihan kualitas bahan baku produk yang dihasilkan Umkm Batik Magenda dilakukan agar menambah omzet atau volume penjualan. UMKM Batik Magenda dalam menentukan motif dan warna menggunakan bahan-bahan alami tetap mengutamakan kualitas produk yang dihasilkan. Hal ini juga yang menjadi daya tarik bagi konsumen yang ditawarkan oleh UMKM Batik Magenda.

UMKM Batik Magenda juga mencoba memproduksi batik dengan memadukan atau mengkominasikan antara motif modern dan motif klasik/ lokal. UMKM Batik Magenda juga memberikan pelayanan kepada konsumen yang hendak membeli dengan beberapa pilihan batik yang tersedia. Tujuan pelayanan tersebut agar konsumen mempunyai pemikiran tentang jenis, warna dan kualitas yang diinginkan. Fakta tersebut sesuai dengan pendapat yang dikemukakan oleh Herlambang,(2014:34) produk merupakan kombinasi barang dan jasa yang dihasilkan oleh perusahaan dan ditawarkan kepada pasar sasaran. Variabel dalam bauran produk yaitu kualitas, ciri khas, gaya, bentuk, merk, pemungkus, pelayanan dan jaminan. Produk yang dibuat haruslah bermanfaat, bermotif dan inovatif bagi konsumen. Hal tersebut sesuai dengan yang diungkapkan oleh manajer UMKM Batik Magenda sebagai berikut:

"Dalam memproduksi barang kami selalu mengutamakan kualitas mulai dari bahan baku, warna dan motif batik, kami sesuaikan dengan permintaan yang diinginkan oleh konsumen mbak.Karena kepuasaan konsumen akan menjadi daya tarik bagi kami untuk selalu meningkatkan pelayanan serta dengan hal tersebut akan menambah pelanggan bagi kami mbak." (Z, 27 th

Pernyataan manajer UMKM Batik Magenda tersebut menunjukkan adanya kesuaian tentang produk yang dihasilkan dengan teori yang dikemukakan peneliti. Bahwasanya produk perusahaan yang selalu menjaga kualitas produk dan memuat kreatifitas pada produk dapat menarik minat konsumen. Pemenuhaan kebutuhan konsumen juga menjadi pertimbangan perusahaan dalam menarik minat konsumen disamping tujuan perusahaan yaitu mendapatkan profit.

Strategi bauran pemasaran ditinjau dari segi harga juga mempunyai peran penting terhadap daya tarik dan kepuasaan konsumen. Harga yang terjangkau dan produk yang mempunyai kualitas juga daya tarik konsumen terhadap perusahaan. Penentuan harga yang diterapkan oleh UMKM Batik Magenda kepada para konsumen mengacu pada kualitas suatu produk tergantung pada bahan baku dan kesulitan dalam proses produksinya. Bahan baku yang berbeda dan kesulitan pengerjaan produk juga mempengaruhi tingkat harga yang ditetapkan oleh perusahaan.

UMKM Batik Magenda berupaya dengan bahan baku yang mempunyai kualitas mampu memberikan harga yang dapat dijangkau oleh para konsumen. Sehingga penetapan harga dapat diterima oleh konsumen. Hal tersebut sesuai dengan yang diungkapkan manajer UMKM Batik Magenda:

“ Produk batik magenda yang sampai saat ini banyak diminati dan dibeli konsumen kebanyakan dari harga yang rendah dan sedang mbak, yang tinggi juga ada sih mbak tapi lebih banyak konsumen yang membeli harga rendah dan sedang mbak." (Z, 27 $\left.{ }^{\text {th }}\right)$ 
Pernyataan diatas sesuai dengan teori yang dikemukakan oleh peneliti bahwa penetapan harga secara tepat dapat meningkatkan volume penjualan dan menarik minat konsumen terhadap UMKM Batik Magenda. Penetapan harga yang dilakukan oleh UMKM Batik Magenda dengan mempertimbangkan kualitas bahan baku yang digunakan dan kesulitan pada saat pengerjaannya. Tingkat harga produk yang mahal, sedang atau murah juga disesuaikan dengan bahan baku yang diinginkan oleh konsumen dengan mempertimbangkan kesulitan dalam pembuatannya.

Strategi bauran pemasaran yang berperan penting dalam suatu usaha salah satunya adalah distribusi. Distribusi yaitu saluran pemasaran yang dilakukan oleh UMKM Batik Magenda Tamanan Kabupaten Bondowoso guna produknya dapat tersalurkan kepada konsumen dengan tepat sasaran. Distribusi yang dilakukan oleh UMKM Batik Magenda melalui penyaluran secara langsung yaitu konsumen bisa langsung datang ke tempat produksi yang ada di Jalan Sukowono sebelah selatan polsek Tamanan Kabupaten Bondowoso. Selain itu, penyaluran secara langsung juga dapat dilakukan dengan cara mengatarkan produk batik kepada konsumen sehingga pemilik UMKM Batik Magenda bisa menjangkau saluran pemasaran yang tepat. Distribusi secara langsung bermanfaat bagi pemilik UMKM Batik Magenda agar produknya dapat tersalurkan dengan terarah pada konsumen yang potensial. Fakta tersebut sesuai dengan pendapat yang diungkapkan oleh Kotler (dalam Keller,2009:241) Pemasaran langsung dapat menjangkau calon pelanggan pada saat yang tepat dan dibaca oleh pelanggan yang leih memiliki prospek.

Berdasarkan data yang diperoleh dari subjek penelitian yaitu pihak UMKM Batik Magenda Tamanan Kabupaten Bondowoso menunjukkan bahwa UMKM Batik Magenda memiliki system pendistribusian secara langsung agar tepat sasaran dan lebih optimal ketangan konsumen. Penyaluran produk Batik Magenda membuat UMKM Batik Magenda Ini bisa bertahan sampai saat ini.

Promosi merupakan kegiatan yang dilakukan oleh UMKM Batik Magenda untuk berusaha mengenalkan produk agar dikenal oleh masyarakat luas. Pengenalan produk yang dilakukan perusahaan dalam hal ini meliputi promosi melalui pameran produk lokal, bekerjasama dengan dikoperindag, dan promosi dari mulut ke mulut. Pameran atau bazaar yang diselenggarakan diskoperindag, koperasi dan lain sebagainya. Rangkaian acara baik pameran maupun bazaar merupakan salah satu promosi yang dilakukan untuk memperkenalkan sekaligus menarik minat konsumen untuk membeli produk batik khas kota Bondowoso sendiri.

Kegiataan promosi ini diharapkan dapat menambah jumlah konsumen untuk dapat membeli produk yang dihasilkan. Fakta tersebut sesuai dengan pendapat Wijayanti,(2012:79) promosi merupakan salah satu bauran marketing yang sangat penting dalam keberhasilan suatu produk atau barang atau jasa atau bisnis apapun. Tujuan promosi adalah agar semua konsumen mengetahui tentang produk atau jasa yang kita tawarkan, baik secara langsung maupun tidak langsung.

Promosi pada hakikatnya merupakan seni untuk merayu pelanggan dan calon konsumen untuk membeli lebih banyak produk yang dihasilkan oleh perusahaan. UMKM Batik Magenda Tamanan Kabupaten Bondowoso mempromosikan produknya melalui komunikasi yang baik dan lancar melalui tatap muka (personal selling) yaitu melalui mulut ke mulut sehingga produk Batik Magenda cepat terdengar ditelinga para konsumen, sehingga konsumen dapat terus melakukan hal yang sama yaitu memberikan informasi tentang Batik Magenda dari mulut ke mulut. Promosi dengan cara berkomunikasi langsung dan meyakinkan kepada konsumen tentang keunggulan produk perusahaan.

Produk yang dihasilkan juga pernah diikutkan pameran produk lokal yang setiap tahunya diadakan.Kegiatan tersebut diharapkan dapat mengenalkan produk kepada masyarakat luas atau lebih dengan istilah publitas. Fakta tersebut sesuai dengan pendapat Herlambang, (2014:34) promosi merupakan kegiatan yang dilakukan oleh perusahaan untuk mengkomunikasikan manfaat dari produknya dan meyakinkan konsumen sasaran untuk membeli. Adapun variabel yang terkandung dalam bauran promosi adalah periklanan, personal selling, promosi penjualan dan publitas. Manajer UMKM Batik Magenda menyatakan :

“Cara promosi paling dasar yang dilakukan kami jika ada konsumen yang datang memesan batik, kami biasa menjelaskan tentang kualitas dan kelebihan yang dimiliki produk batik yang kami miliki. Cara itu kami lakukan agar produk kita dapat dikenal dari mulut ke mulut melalui konsumen." $\left(Z, 27^{\text {th }}\right)$

Berdasarkan pernyataan manajer UMKM Batik Magenda terdapat kesuaian dengan teori yang dikemukakan bahwa salah satu promosi yang dilakukan dengan keyakinan konsumen tentang kualitas produk bisa dicapai dengan cara promosi dari mulut ke mulut. Penerapannya konsumen bukan hanya difungsikan menjadi pembeli, tetapi meyakinkan konsumen lain agar membeli produk dari UMKM Batik Magenda juga. Selain itu, UMKM Batik Magenda juga mempromosikan produknya secara langsung. Promosi tersebut dilakukan melalui media sosial seperti: blog, facebook, bbm dan whatshapp. Beberapa promosi yang dilakukan oleh UMKM Batik Magenda dengan tujuan untuk memperkenalkan, menginformasikan, dan menarik konsumen untuk membeli produk batik magenda, dari beberapa promosi tersebut kini Direct Marketing menjadi pasar sasaran untuk 
konsumen karena media elektronik yang semakin diminati, karena tersedianya berbagai macam media sosial yang dapat digunakan untuk mempromosikan produk. Komunikasi secara langsung yaitu, konsumen bisa secara langsung mendapatkan respon dari produsen walaupun posisi produsen dan konsumen begitu jauh, dikarenakan promosi melalui pemasaran langsung.

\section{PENUTUP}

Kesimpulan

Berdasarkan hasil penelitian dan pembahasan yang sudah dilakukan oleh peneliti menyimpulkan bahwa UMKM Batik Magenda Tamanan Kabupaten Bondowoso dalam strategi pemasarannya menerapkan atau menggunakan strategi bauran pemasaran atau yang lebih dikenal dengan istilah marketing mix dalam memasarkan produknya, yaitu melalui strategi produk, strategi harga, strategi tempat dan strategi promosi.

Strategi produk yang dilakukan oleh UMKM Batik Magenda adalah mengutamakan kualitas produk dari segi bahan baku yang digunakan dan proses produksinya. Selain itu, menyediakan berbagai macam motif dan menjadikan motif daun singkong sebagai ciri khas yang mempunyai daya saing dan mampu menarik minat konsumen. Penentuan harga yang dilakukan oleh UMKM Batik Magenda mengacu pada kesulitan proses produksi dan bahan baku yang digunakan agar tercapai harga yang tepat.

Kegiatan distribusi yang dilakukan oleh UMKM Batik Magenda adalah distribusi langsung antara lain dengan melakukan komunikasi pesanan secara langsung kepada konsumen dan melayani penjualan langsung dari stok produk yang ada digaleri batik. UMKM Batik Magenda juga sering mengikuti pameran, bazar ataupun eventevent tertentu. Selain itu, strategi promosi yang dilakukan adalah dengan penjualan perorangan yaitu, bertatapan langsung dengan konsumen, pengiklanan yaitu kartu nama, dan media sosial seperti; Blog, Bbm, Facebook, Dan Whatsapp. menerapkan potongan harga, dan promosi dari mulut ke mulut.

\section{DAFTAR PUSTAKA}

Herlambang, Susatyo 2014. Basic Marketing (Dasar - Dasar Pemasaran) Cara Mudah Memahami Ilmu Pemasaran. Yogyakarta:Kdt

Kotler, P. Dan Keller,K.L 2009. Manajemen Pemasaran. Edisi 13 Jilid 2. Jakarta:Erlangga

Wijayanti, titik. 2012.Marketing Plan! Perlukah?. Jakarta: PT. Gramedia Pustaka Utama. 